\title{
Ihmiskeskeistä digitalisaatiota ja palvelua etsimässä
}

Toivonen, Marja \& Saari, Eveliina (toim.): Human Centered Digitalization and Services. Translational Systems Sciences vol 19. Singapore, Springer, 2019, 323 sivua.

Yhteiskunnan eri kerrokset läpäisevä digitalisaatio on yksi tämän hetken merkittävimmistä keskustelua aiheuttavista ilmiöistä. Yksi tämän keskustelun aihealue on digitalisaation myötä tapahtuva työelämän ja palveluiden muutos. Digitalisaatio on herättänyt niin toiveita kuin uhkakuvia ja tuonut mukanaan sekä mahdollisuuksia että haasteita. Eräs ajankohtaisista kysymyksistä onkin, mikä tulee olemaan ihmisen rooli ja merkitys yhä lisääntyvän digitalisoinnin ja monipuolistuvan teknologian keskellä? Myös viimeisin Tilastokeskuksen (2019, 1) julkaisema työolotutkimus viestii "digitalisaation läpäisseen suomalaisen työelämän" ja yhä useampi työelämän muutokseen liittyvä tutkimus tarkastelee digitalisaation ja teknologioiden vaikutuksia.

Keskustelu digitalisaation ympärillä on ollut pääsääntöisesti varsin teknologiakeskeistä, ja keskustelua ovat hallinneet paljolti ICT-alan tai tietohallinnon edustajat. Digitalisaation ja teknologian markkinoinnissa painottuvat ajan säästäminen, toiminnan tehostaminen ja uudet mahdollisuudet kehittää palveluita asiakkaille saavutettavammaksi. Viime vuosikymmenen aikana alkoi kuitenkin viritä akateeminen keskustelu digitalisaation ja teknologian käytön inhimillisistä ja sosiaalisista ulottuvuuksista. Miten työtä tullaan organisoimaan teknologian myötä, millä toimintaperiaatteilla esimerkiksi julkisia palveluita tarjotaan kansalaisille ja mitä muutoksia digitalisaatio tuo niihin? Kriittinen ja arvioiva tutkimuskirjallisuus näistä ilmiöistä on ollut vielä sangen vähäistä, mutta aihepiiriä koskevan tutkimuksen määrä on kuitenkin onneksi vahvasti kasvamassa.

Tähän tarpeelliseen ja yhteiskunnallisesti tärkeään keskusteluun tuo oman panoksensa Marja Toivosen (Helsingin yliopisto) ja Eveliina Saaren (Työterveyslaitos) toimittama teos Human-Centered Digitalization and Services, jonka kirjoittamiseen ovat osallistuneet toimittajien lisäksi monet aihepiirin tutkijat. Kirja sai alkunsa Business Finlandin rahoittaman tutkimusprojektin The revolution of service economy - Human being at the core of digitalisation (2015-2018) myötä, ja teos esittelee muun muassa tämän projektin tutkimustuloksia.

Kirja esittelee monipuolisesti tutkimuksia digitalisaation ja teknologian vaikutuksista palveluiden, työn ja arkielämän näkökulmista käsin. Teos summaa aihepiirin tutkimustuloksia eri maista viimeisen kahdenkymmenen vuoden ajalta. Yksi teoksen pääargumentti on, että digitalisaatio mahdollistaa uudentyyppisten palveluiden ja työn toteuttamisen, mutta huomio tarkastelussa painottuu vielä hyvin paljon teknologioihin ja laitteisiin ihmiskeskeisen näkökulman kustannuksella. Teoksessa korostetaan myös sitä, miten palveluiden ja työn kehittämisessä digitalisaation ja teknologian avulla tulisi kiinnittää huomiota työntekijöiden ja asiakkaiden rooleihin, ja heitä tulisi osallistaa enemmän kehittämistyöhön, toimeenpanoon ja arviointiin. Muutoksen ei pitäisi tulla pelkästään ylhäältä annettuna organisaation johdolta, johon työntekijät ja 
asiakkaat sitten sopeutuvat passiivisesti, vaan he voisivat olla muutoksessa aktiivisia innovaattoreita. Näin varmistetaan työn laatu ja työntekijöiden hyvinvointi kestävällä tavalla, vahvistetaan eri osapuolten välistä luottamusta ja mahdollistetaan pitkällä aikavälillä laadukkaat digitaaliset palvelut asiakkaille. Digitalisaatio merkitsee yhteiskunnallisen paradigman muutosta ja on laadullisesti erilainen ilmiö kuin on tähän mennessä palveluiden kehittämisessä ja työelämän muutoksessa kohdattu. Ilmiö vaatii siksi tarkastelua ja tutkimustietoa inhimillisistä ja sosiaalisista näkökulmista käsin.

Teoksen eri luvuissa esitetään tutkimustietoa sekä teoreettisen keskustelun että empiiristen tapaustutkimusten avulla erilaisista näkökulmista. Monessa luvussa tarkastellaan sosiaali- ja terveydenhuollon alan digitalisaatiota ja palveluinnovointia, kuten teknologian hyödyntämistä hoitajien ja lääkäreiden työssä tai vanhuspalveluissa. Teoksessa esitetään myös tutkimuksia palvelukehittämisestä ja digitalisaation vaikutuksista muun muassa perheiden ja nuorten elämään, koulutusalaan ja muuhun asiantuntijatyöhön.

Kirja on jaettu neljään osaan, joista ensimmäinen esittelee digitalisaation, palveluinnovoinnin ja -kehittämisen erilaisia teoreettisia lähestymistapoja, kuten systeemiajattelua tai käytäntölähtöistä palveluinnovointia (practise-based innovation). Toinen osa käy läpi lähestymistapoja ja tapaustutkimuksia inhimillisen ja sosiaalisen vuorovaikutuksen yhteyksistä digitalisaatioon ja palvelukontekstiin. Tutkimusaiheina ovat esimerkiksi pakolaisten ja maahanmuuttajien monialaisten palveluiden kehittämisen haasteet, yhteiskehittäminen (co-creation) sekä teknologiset toimintahäiriöt innovoinnin lähteenä.

Kolmas osa puolestaan esittelee tutkimuksia digitaalisten ratkaisujen ja välineiden tarjoamista uusista mahdollisuuksista palveluiden toteuttamiselle ja innovoinnille. Artikkeleissa on tutkittu esimerkiksi robottien hyödyntämistä vanhuspalveluissa tai tietojärjestelmien käytön vaikutusta hoitajatyöhön hoi- van näkökulmasta. Neljäs ja viimeinen osa nostaa esiin digitaalisten ja inhimillisten resurssien välisen yhteyden ja korostaa teoksen pääteemaa: ihmiskeskeisyyttä digitalisaatiossa. Tässä osassa käsitellään muun muassa datan sosiaalista hyödyntämistä, vanhuspalveluiden digitalisaation sosiaalista kestävyyttä sekä digitaalisten resurssien ja inhimillisten resurssien vuorovaikutusta. Kirjan rakenne ja jaottelu näihin neljään osaan toimii sangen loogisesti. Valitut tutkimusartikkelit sopivat osioiden sisältöihin perustellusti ja konkretisoivat niissä käsiteltäviä teemoja.

Teoksen yhtenä päätarkoituksena on esitellä tutkimusta ihmiskeskeisestä digitalisaatiosta, palveluiden kehittämisestä ja innovoinnista eri näkökulmista. Tutkimustuloksiin perustuen tutkijat painottavat työntekijöiden ja asiakkaiden eli palveluiden parissa toimivien ihmisten merkitystä digitalisoinnissa ja kehittämistyössä. Tämä tuodaan esiin kirjan esipuheessa ja sisällön esittelyssä. Vaikka teos päättyy viimeisessä osassa enemmän pääteemaansa eli ihmiskeskeisen digitalisaation käsittelyyn, lukija jää kuitenkin kaipaamaan lopuksi jonkinlaista tiivistä yhteenvetoa tai johtopäätöksiä. Yhteenvedossa olisi voitu pohtia ja arvioida, mihin kysymyksiin kirjan luvut ovat vastanneet ja mihin taas eivät, mistä aihealueista ei keskusteltu tässä teoksessa ja mitä olisi syytä tutkia lisää. Yksi tällainen aihealue olisi voinut olla esimerkiksi johtamisen merkitystä tai johtajien ja esimiesten roolia tarkasteleva tutkimus teoksen aihepiirin näkökulmasta.

Lisäpohdintana olisi voinut myös arvioida tämänhetkistä kehityssuuntaa ja tulevaisuudenkuvaa: Onko palveluiden ja työn kehittämisessä digitalisaation avulla sisäistetty ihmiskeskeinen näkökulma ja sen mukaiset periaatteet vai eteneekö kehitys kenties päinvastaiseen suuntaan? Tutkimusartikkeleissa arvioidaan yleisesti kyseisten tutkimusten mahdolliset rajoitteet ja jatkotutkimustarpeet, mutta näiden lisäksi teoksen loppu olisi kaivannut näitä pohdintoja ruotivaa ja arvioivaa yhteenvetoa. Tämä auttaisi myös sellaista luki- 
jaa, joka ei ole syvällisesti perehtynyt aihepiirin tutkimuksiin, jäsentämään teoksen eri lukujen monipuolista sisältöä sekä sisäistämään ja arvioimaan sen pääviestejä.

Loppujen lopuksi teos tarjoaa monipuolisesti tutkimustietoa ja pohdintaa herättäviä näkökulmia ihmiskeskeiseen digitalisaatioon sekä palvelukehittämiseen ja suoriutuu tehtävästään kiitettävästi. Teosta voi suositella ylipäätään kaikille palvelukehittämisestä sekä digitalisaation vaikutuksista kiinnostuneille, kuten kehittämistyötä tekeville asiantuntijoille tai aihepiirin tutkijoille. Teoksen luvut kuitenkin edellyttävät lukijalta jonkinlaisia esitietoja tai perehtyneisyyttä digitalisaatioon, palveluiden kehittämiseen ja innovointiin tai työelämän muutokseen. Toivottavasti teos saa tulevan vuosikymmenen aikana jatko-osan, joka edistäisi ja uudistaisi tutkimusta tästä tärkeästä aihepiiristä, jolla on yhä vain kasvava yhteiskunnallinen merkitys.

\section{Kirjoittaja}

Joonas Karhinen, YTM, tohtorikoulutettava, Jyväskylän yliopisto, sähköposti:

joonas.p.karhinen@jyu.fi

\section{Kirjallisuus}

Tilastokeskus (2019). Työolot 2018, Työolojen neljä vuosikymmentä. <URL:https://www.stat. fi/til/tyoolot/2018/tyoolot_2018_2019-12-11_ tie_001_fi.html>. Luettu 3.2.2020. 